This item was submitted to Loughborough's Research Repository by the author.

Items in Figshare are protected by copyright, with all rights reserved, unless otherwise indicated.

\title{
The future of peer-to-peer lending in China
}

PLEASE CITE THE PUBLISHED VERSION

https://dx.doi.org/10.2139/ssrn.3524395

PUBLISHER

Elsevier

VERSION

AO (Author's Original)

LICENCE

CC BY-NC-ND 4.0

REPOSITORY RECORD

Chen, Ding, Anil Savio Kavuri, and Alistair Milne. 2020. "The Future of Peer-to-peer Lending in China". Loughborough University. https://hdl.handle.net/2134/13092878.v1. 


\title{
The Future of Peer-to-Peer lending in China
}

\author{
DING CHEN ${ }^{1}$; ANIL SAVIO KAVURI ${ }^{23}$; ALISTAIR MILNE ${ }^{3}$
}

\begin{abstract}
${ }^{1}$ School of Law, University of Sheffield, UK, ding.chen@sheffield.ac.uk (corresponding author) ${ }^{2}$ Crawford School of Public Policy, Australian National University, Australia ${ }^{3}$ School of Business and Economics, Loughborough University, UK, a.s.kavuri@lboro.ac.uk; a.k.I.milne@lboro.ac.uk
\end{abstract}

\begin{abstract}
This paper reviews the development and assesses the future of Peer-to-Peer (P2P) lending in China. Chinese P2P lending has expanded by a factor of 60 over the four years from 2013 and 2017, becoming much greater, both in absolute terms and relative to the size of the economy, than in any other country. The industry though has been plagued by problematic often fraudulent business models in what was, until 2015 , effectively a regulatory vacuum. A strict new regulatory regime is now being introduced but its introduction, especially the requirements on capital requirements and registration, are substantially reducing the volume of P2P lending. We consider the future of P2P lending concluding it's facing substantial uncertainties.
\end{abstract}

Keywords: P2P lending, investor protection, banking, banking competition, financial technology, financial regulation.

JEL Classifications: G21, G23, G28, K22 


\section{Introduction}

China has seen by far the most spectacular growth in P2P of any country worldwide (Tables 1 and 2). This tremendous growth has however taken place within what was effectively a regulatory vacuum. The recent establishment of a regulatory regime for P2P lending in China, following a wave of scandals in the sector, is now resulting in a sharp contraction in Chinese P2P lending.

Table 1: The volume of P2P SME lending in the leading nine countries around the world.

\begin{tabular}{|c|c|c|c|c|c|}
\hline \multirow[t]{2}{*}{ Countries } & \multicolumn{5}{|c|}{ P2P SME Lending in million } \\
\hline & 2013 & 2014 & 2015 & 2016 & 2017 \\
\hline China (\$) & 1,440 & 8,040 & 39,630 & 57,780 & 97,430 \\
\hline US (\$) & 342 & 968 & 2,580 & 1,330 & 1,450 \\
\hline UK (f) & 193 & 749 & 881 & 1,232 & 2,039 \\
\hline Germany (€) & - & 6.1 & 48.7 & 23.3 & 71.4 \\
\hline France $(€)$ & 0.2 & 8.0 & 28.2 & 70.9 & 88.0 \\
\hline Australia (\$) & - & - & 7.9 & 6.9 & 23.1 \\
\hline Switzerland $(€)$ & & & & & 331.3 \\
\hline N Zealand (\$) & - & - & - & 7.5 & 14.2 \\
\hline Japan (\$) & 78.5 & 107.1 & 323.5 & 164.8 & 188.9 \\
\hline
\end{tabular}

Source: author's calculations using data from the Cambridge Centre for Alternative Finance. 
Table 2: The volume of Total P2P lending in the leading nine countries around the world.

\begin{tabular}{|l|r|r|r|r|r|}
\hline Countries & \multicolumn{5}{|c|}{ Total P2P lending millions } \\
\hline China (\$) & $\mathbf{2 0 1 3}$ & $\mathbf{2 0 1 4}$ & $\mathbf{2 0 1 5}$ & $\mathbf{2 0 1 6}$ & $\mathbf{2 0 1 7}$ \\
\hline US (\$) & 5,520 & 23,820 & 97,580 & 201,310 & 327,800 \\
\hline UK (£) & 3,176 & 8,742 & 21,282 & 23,420 & 17,340 \\
\hline Germany (€) & 480 & 1,296 & 2,399 & 3,548 & 4,660 \\
\hline France (€) & 36 & 87 & 185 & 205 & 396 \\
\hline Australia (\$) & 43 & 88 & 163 & 250 & 381 \\
\hline Switzerland (€) & 2 & 16 & 70 & 165 & 365 \\
\hline N Zealand (\$) & - & - & & & \\
\hline Japan (\$) & 0 & 14 & 245 & 178 & 242 \\
\hline
\end{tabular}

Source: author's calculations using data from the Cambridge Centre for Alternative Finance.

This article reviews the rise of peer-to-peer (P2P) in China and the prospects for its future following the recent regulatory reforms. ${ }^{1}$ It views these developments from the broader perspective of financial regulation and the light of similar challenges of reregulation of P2P lending in the other leading jurisdictions for P2P lending, the US and the UK. Our principal

\footnotetext{
${ }^{1}$ Such platforms are referred to by a variety of terms including 'P2P lending', 'marketplace lending' and 'loanbased crowdfunding'. They can be distinguished from other technology-based non-bank 'balance sheet lenders', who instead hold loans on their own balance sheets funded more conventionally using a mixture of debt and equity. The term 'marketplace lending' is also sometimes used, especially in the US, to refer collectively to both alternative lending platforms and non-bank balance sheet lenders. Here P2P lending refers to the technology-based platforms that allow investors to participate as investors in loan assets, with a direct claim on payment of interest and repayments of principal. The platform itself has no claim on these payments, but instead earns fees for related services including the assessment of credit risk, the matching of investors with borrowers, and the servicing of loans including the collection and allocation of payments of interest and principal.
} 
finding is that China is witnessing a particularly marked change in regulatory stance. While other jurisdictions are also tightening their regulation of P2P lending, the 'swing of the regulatory pendulum' is much greater in China than elsewhere. Chinese P2P lending was established and grew so extraordinarily fast in what was effectively a regulatory vacuum. The Chinese authorities now appear to be developing a much tighter regulatory regime for P2P lending than anywhere else. The future of Chinese P2P lending platforms is therefore highly uncertain.

The paper is organized as follows. Section 2 describes the growth of P2P lending in China. Section 3 documents the emerging problems with P2P business models in China and the resulting new regulatory regime that aims to prevent further problems. Section 4 compares this new regulatory regime with that established in the US and the UK. Section 5 assesses the uncertain future prospects for Chinese P2P lending. Section 6 is the summary and conclusions of our analysis.

\section{The growth of $P 2 P$ lending in China}

This section describes the rapid growth of P2P lending in China, explores the reasons for its spectacular rise and the weakness of the business models adopted in Chinese P2P lending. China's first online lending platform, PPDAI group launched in 2007. The industry has gone grown spectacularly over the subsequent decade, with the number of platforms reaching 2,595 in 2015 (Wangdai Zhijia); ${ }^{2}$ and the volume of lending the biggest in the world (Wildau and Jia 2018. Table 1). Even as late as June 2018, the industry reportedly channelled loans from 4.1 million investors to 4.3 million borrowers (Wildau and Jia 2018).

\footnotetext{
${ }^{2}$ There are no definitive statistics on the number of platforms. The number given here is from the same source as Table 2.
} 
Table 3 provides some more detailed statistics on Chinese P2P lending.

Table 3 The development of Chinese P2P lending

\begin{tabular}{|l|l|l|l|l|l|l|}
\hline Key indicators & $\mathbf{2 0 1 1}$ & $\mathbf{2 0 1 2}$ & $\mathbf{2 0 1 3}$ & $\mathbf{2 0 1 4}$ & $\mathbf{2 0 1 5}$ & $\mathbf{2 0 1 6}$ \\
\hline $\begin{array}{l}\text { Number of } \\
\text { providers }\end{array}$ & 50 & 200 & 800 & 1,575 & 2,595 & 2,448 \\
\hline $\begin{array}{l}\text { Number of } \\
\text { investors (10,000) }\end{array}$ & - & - & 25 & 116 & 586 & 1,375 \\
\hline $\begin{array}{l}\text { Number of } \\
\text { borrowers(10,000) }\end{array}$ & - & 15 & 63 & 285 & 876 \\
\hline $\begin{array}{l}\text { Volume of } \\
\text { transactions per } \\
\text { year(billion US\$) }\end{array}$ & 0.5 & 3.2 & 15.9 & 37.9 & 147.3 & 309.6 \\
\hline $\begin{array}{l}\text { Average rate of } \\
\text { return (\%) }\end{array}$ & & 19.1 & 21.3 & 17.9 & 13.3 & 10.5 \\
\hline $\begin{array}{l}\text { Average } \\
\text { maturity(months) }\end{array}$ & & 6.0 & 4.7 & 6.1 & 6.8 & 7.9 \\
\hline
\end{tabular}

Source: Wangdai Zhijia, 2014, 2015, 2016

This rapid growth of the Chinese P2P sector is commonly attributed to two intertwined factors:

- China's inefficient financial system

- The Chinese authorities' hands-off approach to its regulation

We discuss each of these in turn.

\section{China's inefficient financial system}

Despite the transformation of the real economy, the Chinese financial system can still be characterised as one of 'financial repression' i.e. with laws and policies instituted in developing economies to control financial systems by preventing them from functioning at their full capacity (McKinnon,1973). In a seriously repressed financial system, the interest rate is kept artificially low by the state so that cheap loans become available to borrowers, a de facto tax on savers. The policy of financial repression has been implemented by the 
Chinese government since the establishment of the People's Republic of China (PRC) in 1949. Banks had to comply with a floor for lending rates and a ceiling for deposits imposed by the People's Bank of China (PBOC) (the floor has been removed since 2013 but the ceiling remains). The deposit rate has been kept low, to the extent real interest rate of being negative in some periods (Lardy, 1998). The emergence of P2P sector met Chinese savers' demand for a better investment alternative and therefore attracted millions of retail investors in only a few years. It is reported that more than 60 percent of the China' P2P platforms offered an annual yield in the range between 12 and 18 percent or between 18 and 24 percent, which is considerably higher than the 3.3 percent paid by commercial banks (Shen, 2016).

China's financial system is dominated by state-owned banks which has a preference for lending to state-owned enterprises (SOES) or large private companies and leaves a large number of small and medium sized enterprises (SMEs) under-served. ${ }^{3}$ Only 25 percent of Chinese firms report having a loan or line of credit, among small firms the figure was 14 percent (Kuntchev et al., 2012). In the Enterprise Survey, Chinese firms report access to finance as their biggest business environment obstacle. Among small firms, just 4 percent use banks to finance investments, and bank financing accounts for less than 1 percent of funding for investments (Kuntchev et al., 2012).

Apart from political bias, SMEs financing is a worldwide challenge. Lack of credit information and under-collateralisation are considered to be major factors accounting for the financial constraints faced by SMEs. Traditional banks have been proved to be ill-equipped to tackle this challenge. P2P lending platforms seemed to offer a better solution by utilizing automated processes to reduce costs and credit risk models that use non-traditional data. Quick decision making and no collateral requirement rendered P2P sector an important financial source to SMEs in China, with 20 to 40 percent of all loans flowing into SMEs, a sharp contrast with the U.S. (ACCA 2015, Table 1 and Table 2 above).

\footnotetext{
${ }^{3}$ Small enterprises are defined as firms with 5-19 employees; Medium, defined as firms with 20-99 employees; and Large, defined as firms with 100 or more employees.
} 


\section{The Chinese authorities' hands-off approach to its regulation}

Chinese authority's hands-off approach to regulation has been a further driver for the rapid expansion of P2P sector. Prior to July 2015, the P2P sector was completely left unregulated. This seemed to be odd at first given China's financial sector has always been tightly controlled by the government. Chinese government's laisse faire attitude appears to have been based on two considerations. The first one was to find an alternative financing source for SMEs. SMEs now play a significant role in China's economy: they contribute 70 per cent of employment, 60 per cent of GDP, 50 per cent of tax revenue, and holding 65 per cent of patents (Sheng, Ng and Edelmann 2013).

Recognizing their economic significance, over the past two decades, the Chinese government has made various attempts to ease the financial stress faced by SMEs, especially after the 2008 financial crisis which led to a significant decline in China exports. However, none of these measures seemed to work effectively. As a result, the majority of Chinese SMEs had to heavily rely on informal lending (minjian jiedai) (interpersonal lending based on social network) for external financing (Allen et al., 2005). Things got worse when the market for informal lending was hit by a crisis originating from Wenzhou in April 2011 and peaked in September of the same year. Although the first P2P platform appeared in China as early as in 2007, it was not till 2012, i.e. after the Wenzhou financial crisis, that the industry really started to surge (as shown in tables 1 and 2 ). If the government's inaction during 2007-2011 was largely due to the negligible size of the industry, its continual noninterference after 2012 is most easily understood as a purposive strategy that trying to develop the P2P sector into an alternative financing source for SMEs.

The second reason behind the initial laisse faire approach was the Chinese authority's failure to understand the risk emerging from P2P lending. Although the China's P2P sector has become the largest market in the world, it remains a minuscule slice of overall borrowing: it only accounted for 0.3 percent of total banking assets in 2018 (Moody's Investor Service, 2018). The relative small size of P2P sector led the Chinese authority to believe that there was no serious concern about substantial risk, in the worst case, it could 
simply close the whole industry down. ${ }^{4}$ However, this assessment was based on its understanding of traditional financial service which later proved to be a considerable underestimation of the scale of risk relating to Fintech-enabled financial services.

In the absence of regulation, the majority of Chinese P2P platforms deviated from the original information intermediary business model and adopted the 'guarantee' model in order to attract investors. ${ }^{5}$ Under the guarantee model, a P2P platform not only matches lenders and borrowers but also provides guarantees for the lender's principal and interests usually by themselves, or by cooperating with an associated guarantee company (P2P Research Group 2016). If a loan default occurs, the platform or the guarantee company compensates lenders and the lenders transfer the loan claims to the platform or the guarantee company for the follow-up debt collection. In addition, a platform, not the lender, often becomes the one that originated loans to borrowers. As a result, there is no direct contractual relationship between the lenders and borrowers, instead, they transact with the platform separately (P2P Research Group 2016).

By adopting the guarantee model, most China's P2P platforms were actually playing a similar role to that of the traditional bank, but subjected to no regulation. Chinese P2P platforms usually set up and registered themselves as consultancy firms and therefore their average size has been small. As of the middle of 2014, the averaged registered capital of the platforms was about RMB23.7mn $(\$ 3.8 \mathrm{mn})$ and most platforms had registered capital between RMB5mn (\$0.8mn) to RMB20mn (\$3.2mn) (Shen 2015). Only 54 platforms had registered capital of above RMB50mn (\$8.1mn) (Lufax 2015). It is hard to conceive how these platforms could fulfil their promises to investors with this thin capital base. They have either to rely on their shareholders for financial assistance, or to pay the earlier investors

\footnotetext{
${ }^{4}$ This is consistent with the 'trial and error' reform strategy since 1978, examples including the establishment of special economic zones and stock market. Deng Xiaoping made the following famous statement on stock markets during his Southern Tour "... some people insist stock is the product of capitalism. We conducted some experiments on stocks in Shanghai and Shenzhen, and the result has proven a success. Therefore, certain aspects of capitalism can be adopted by socialism. We should not be worried about making mistakes. We can close it [the stock exchange] and re-open it later. Nothing is 100\% perfect." Caixin, 2013.

5 There are four business models in China's P2P sector, apart from the guarantee module, also include the original information intermediary model, for example, Paipaidai; the asset securitization model, examples like Lufax; and the debt assignment module, like CreditEase or Yixin.
} 
with funds from more recent investors, that is, running a Ponzi scheme. Many platforms, as revealed later, were indeed scams from the outset.

\section{The belated regulation of Chinese P2P lending}

This section describes the emergence of problems in Chinese P2P lending, the subsequent and ongoing efforts at regulation and the consequences for the industry.

\section{Rising levels of platform failure}

Problems with the business models of Chinese P2P lending first came to prominence in 2015 when around 896 P2P platforms got into trouble (The 2016 Blue Book of Internet Finance), of which more than half was due to fraud. In particular, the downfall of Ezubao at the end of this year put the troubled industry in the spotlight.

Ezubao used to be one of the highest-profile platforms, by 8 December 2015, its trading volume totalled at RMB 74.568 billion, involving some 909,500 investors (Caiing2018). It was found that 95 percent of projects financed through Ezubao were fake, fabricated by the platform. Ezubao scandal soon became frontpage news on all of China's tech sites and tens of thousands of angry investors went on street to protest. Some of them even travelled to Beijing to protest outside the central government offices (Caiing2018). The scale of platform failures and their economic and social consequences were far greater than the government had anticipated. As described in the next sub-section, it responded with the introduction of a comprehensive regulatory regime.

The number of platforms that ceased trading further increased in the following three years 206-2018 (Table 4). 2018, as the new regulations came into effect, saw a major increase in the number of affected investors and volume of loans on failed platforms. In total, by mid2019, more than 2 million investors with loan investments totalling some RMB117.21bn (\$26.9bn) had been caught up in failing platforms. 
Table 4: P2P platforms failures

\begin{tabular}{|l|l|l|l|}
\hline Key indicators & $\begin{array}{l}\text { Numbers of platforms that } \\
\text { went bust or found to be } \\
\text { problematic (cumulative) }\end{array}$ & $\begin{array}{l}\text { Number of } \\
\text { investors involved } \\
(1,000)\end{array}$ & $\begin{array}{l}\text { Outstanding P2P loans } \\
\text { involved (RMBbn) }\end{array}$ \\
\hline $\mathbf{2 0 1 4}$ & 395 & 63 & $6.84(\$ 1.1 \mathrm{bn})$ \\
\hline $\mathbf{2 0 1 5}$ & 1,686 & 272 & $16.79(\$ 2.7 \mathrm{bn})$ \\
\hline $\mathbf{2 0 1 6}$ & 3,407 & 454 & $26.59(\$ 4.2 \mathrm{bn})$ \\
\hline $\mathbf{2 0 1 7}$ & 4,129 & 576 & $33.24(\$ 5.2 \mathrm{bn})$ \\
\hline $\mathbf{2 0 1 8}$ & 5,417 & 2,154 & $176.65(\$ 26.8 \mathrm{bn})$ \\
\hline $\mathbf{2 0 1 9}$ & 5,433 & 2,162 & $177.21(\$ 26.9 \mathrm{bn})$ \\
\hline
\end{tabular}

Source: Wangdai Zhijia

\section{Regulatory Reform}

With the increasingly visible problems with P2P business models, the Chinese government quickly abandoned its laissez faire approach and established a detailed, comprehensive regulatory framework, beginning in July 2015. It consists of four key documents (referred to '1+3' framework ):

1. The 2016 Interim Measures on Online Lending (2016 Interim Measures);

2. The 2015 Guideline on the Administration of Recordation and Registration of Online Lending Information Intermediary Institutions (2016 Guideline on Online Lending Registration);

3. The 2015 Guideline on Custodian Business for Online Lending Funds (2015 Guideline on Custodian Business); and

4. The 2017 Guideline on Information Disclosure by Online Lending Information Intermediary Institutions (2017 Guideline on Information Disclosure).

Of these, the 2016 Interim Measures is the corner stone of the regulatory regime. It contains a total of 47 articles that cover all important aspects of the online lending industry. 
Contravention of the 2016 Interim Measures can lead to administrative or even criminal penalty.

The three guidelines are implementing rules of the 2016 Interim Measures, each focuses on a particular issue. As well as these regulations that specific to online lending industry, P2P platforms are also subject to general legal rules, in particular Company Law, Contract Law, Anti-competition Law, Consumer Protection Law and Anti-Money Laundering (AML) Law.

The regulatory model created by the 2016 Interim Measures is sometimes described as a 'dual supervisory model'. At central level, the China Banking and Insurance Regulatory Commission (CBIRC) acts as the lead regulator for P2P industry, responsible for developing rules for supervision and administration of the business activities of platforms as well as carry out regulation of business conduct. In the meanwhile, provincial governments are authorized to supervise P2P platforms within their respective jurisdictions, in particular regarding their recordation and registration. They also have the power to impose penalties on misbehaving platforms. Any particular platform is therefore subject to a dual supervision of the CBIRC and provincial government where it is registered.

In addition, the National Internet Finance Association (NIFA) run by the central bank and with 400 members was also recruited to regulate China's P2P sector. Article 34 of the 2016 Interim Measures delegates the NIFA the power to establish rules of self-regulation and industry standards, to accept complaints and reporting, to conduct self-inspection, and so on. Given the limited resources of regulators and the challenging nature of the P2P industry, the NIFA is expected to play an important role under this new current regime.

The regulation aims to eliminate fraudulent or poor business practices that plagued the industry and re-establish all platforms as information intermediaries. Under the current regulation, a P2P platform must separate its own funds from the funds of lenders and borrowers. ${ }^{6}$ The funds of lenders and borrowers must be in custody of a qualified

\footnotetext{
${ }^{6}$ Article 28 of 2016 Interim Measures
} 
commercial bank. ${ }^{7}$ As an information intermediary, a platform is now subject to an obligation to make truthful, adequate, complete and timely information disclosure to the public concerning the platform itself such as organization and operation. ${ }^{8}$ It is also obligated to disclose basic information regarding the borrowers to lenders ex ante, and to make continuous disclosure regarding borrowers' financial status and factors that may affect their repayment capability. ${ }^{9}$ A platform needs to submit an information disclosure announcement together with relevant documents periodically to the local government where it is registered and places them at its registry house for public inspection. ${ }^{10}$ In addition, the information submitted by a platform must be verified by a third party intermediaries like accounting firms, law firms. ${ }^{11}$

Moreover, the regulation also provides that the balance of loans of the same natural person on one online lending platform cannot exceed RMB 200,000; for a legal person or any other organization, the upper limit is set as RMB 1 million. There are further caps on the total balance of loans obtained by the same person from different online lending platforms: for a natural person, it is capped at RMB 1 million, for a legal person it is capped at RMB 5 million.

The above requirements, though they can be costly, are definite and clear and therefore relatively easy for platforms (at least those large, well-operating ones) to meet. The protracted and changeable scheme of registration, by contrast, has been a serious challenge to the industry. Art 5 of the 2016 Interim Measure provides that all platforms must conduct recordation and registration with the local financial regulatory authority at the place where it is based. A platform that fails to go through the new procedure will be banned from continual operation. More detailed requirements are laid down by the 2016 Guideline on Online Lending Registration ${ }^{12}$ and the initial deadline for registration was set in June 2018. This was then delayed. On 13 August, the Task Force of Online Lending Rectification issued a

\footnotetext{
${ }^{7}$ Above

${ }^{8} 2017$ Guideline on Information Disclosure, Article 2; Chapter 2 specifies the content of the required information.

${ }^{9} 2017$ Guideline , Article 9

102016 Interim Measures, Article 31

${ }^{11} 2016$ Interim Measures, Article 31

${ }^{12}$ Chapter 2
} 
'Checklist for the Compliance of Online Lending Information Intermediaries' (108 Checklist) which established a uniform standard for recordation and registration for all P2P platforms in China and set a new deadline in December 2018.

This was followed by further delay and further change. 8 April 2019, media revealed the details of a new pilot registration programme. ${ }^{13}$ According to the pilot programme, platforms will be categorized as national and regional platforms. In order to register as a national platform, a platform must have a minimum paid-up capital of RMB0.5bn; for a regional platform, the threshold is RMB50mn. The pilot registration programme will require national platforms to hold general risk reserves equal to 3 per cent of the lending made through their firm and set aside an amount equivalent to 6 per cent of each borrowing as a loan-loss provision for lenders. The ratios for regional platforms will be 1 per cent and 3 per cent, respectively (Yiling Caijing, 2019). Although this document has widespread online, it never officially published which casts further doubts on the prospect of registration.

\section{Consequences for the industry}

The heavily intensified focus on regulating the P2P industry and a general governmental crackdown on high-risk financing has caused the close down of many hundreds' P2P platforms since 2015. It has already seen an immense drop in the number of Chinese P2P lending platforms by $50 \%$ to 1,021 during 2018. At the end of August 2019, the number further shrunk to 708 (Wangdai Zhijia). Bloomberg has predicted a further drop of $70 \%$ with leaving only 300 P2P platforms in the market by the end of 2019 (Liu, 2019).

Even the most prominent platforms have not escaped unscathed. These include the collapse of Tuandai and of Hongling Capital. The former firm had about 220,000 lenders and borrowers and a loan balance of RMB 14.5 billion, while the latter was one of the longestoperating P2P platforms in China.

Since 2017, the Chinese P2P market has been experiencing a dramatic shrinkage- Total monthly volume of China's P2P lending has fallen from a peak of RMB253bn (\$37.4bn) in June of 2017 to about RMB90bn (\$13.1bn) in July of 2019; about RMB 667bn (\$97.0bn) in

\footnotetext{
${ }^{13}$ The Pilot Programme for the Registration of Online Lending Information Intermidies.
} 
loans are still outstanding in mid-2019, down from about RMB1,060bn (\$151.7bn) in May 2018 (Wangdai Zhijia). These are consistent with the annual figures shown in Table 1 and represent a fall in lending volumes to around one-third from their 2017 levels (though the volume of lending is still substantially greater than in either the US or the UK, the countries outside of China with the largest P2P lending volumes).

The retrenchment of the market has severe consequences for investors, who in many cases have suffered life-altering losses. This has led to protests by ordinary people that have verged on mass unrest. Last year, two sporting stadiums in the city of Hangzhou, where many P2P companies are based, were converted into makeshift petition centers in order to handle the volume of complaints against online lenders. A number of business leaders in the P2P industry have fled China or vanished this year, while many others have been detained, prosecuted or convicted.

\section{International comparisons: regulation in the US and the UK}

This section compares the new Chinese regime for regulation of P2P lending with that obtaining in the US and in the UK. The key issue in both countries has been investor protection. ${ }^{14}$ The main point emerging from these international comparisons is that, in both jurisdictions, the protection of retail investors has required substantial and detailed disclosure requirements. It is made more than clear to investors that what they are investing in is not a bank deposit and involves much significant investment risks.

As a consequence, the major platforms in both the US and the UK have come to rely on institutional investors to fund a substantial proportion of loans intermediated on their platforms. In the US some two-thirds of funding on both Prosper and LendingClub is from institutional investors. In the UK more than half of the funding of the two largest platforms, Zopa and Funding Circle is institutional.

US

From 2006 until 2008, US alternative lending developed with relatively little regulatory

\footnotetext{
${ }^{14}$ The other major issue is compliance with rules and regulations protecting consumer borrowers, a particularly complex issue in the US since these are set at state not federal level. See Chen, Kavuri and Milne (2020 forthcoming) for discussion.
} 
oversight other than that of existing banking and consumer lending regulation. Subsequently two major developments stand out.

- In 2008 Securities and Exchange Commission (SEC) ruled that the 'notes' (claims on payments of loan interest and principal) issued by platforms to investors were not exempt from securities laws and had to be registered with the SEC.

- In 2015 the SEC issued detailed rules on how these securities laws were to be applied to alternative lending platforms.

This regulatory approach, imposing strong protections on the sale of notes to retail investors, has been one of the main reasons why alternative lending in the US is now overwhelmingly an institutional investor not retail investor asset class.

The initial years for US alternative lending platforms 2006-2008, in a deteriorating credit environment, were difficult for the nascent industry with high default rates raising obvious concerns about investor protection. ${ }^{15}$ A key development in investor protection regulation was in November 2008, when the SEC entered a cease-and-desist order against Prosper stating that it had been selling securities which must under US securities law be registered with the SEC (see Lo 2016a). ${ }^{16}$ In response, the legal compliance of platforms changed, with investors now required to hold non-recourse notes issued under a 'shelf registration' with the SEC (i.e. a single registration covering multiple note issues), each note representing claims on the payments of borrower interest and principal.

This was a material difference to their business models. In order to sell these notes to a broad investor based, the platforms had to comply with the demanding requirements for registration and provision of investor information under the Truth in Securities Act and Securities Exchange Act (1933) as well as complying with all requirements for offering advice in securities investment and further requirements if they support a secondary market for resale of investments. ${ }^{17}$ The substantial burden of SEC registration, together with the

\footnotetext{
15 Lo (2016a) reports from press coverage that 'Even as the industry grew, lenders bore painfully high default rates-Prosper was charging off more than $20 \%$ of loans issued before 2008, while LendingClub fared better, but still had $8.5 \%$ of its pre-2008 loans in default.'

${ }^{16}$ This and following paragraphs are again based substantially on (Manbeck and Franson, 2018).

17 Manbeck and Franson (2018) highlight the compliance costs for marketplace platforms who offer notes i.e. for alternative lending platforms when compared with balance sheet lenders.: "The SEC registration process is
} 
accompanying obligation to comply with investment advice and the 'blue sky' securities laws of all states where investor notes were sold led to rapid industry consolidation. This consolidation left only two platforms surviving - those of Prosper and LendingClub.

As both Prosper and LendingClub have demonstrated there is a substantial market for investment in platform loans amongst institutional investors. Sale of notes to institutional investors or other "accredited investors" does not require the compliance costs of shelf registration. ${ }^{18}$

UK

Similar issues of investor protection have emerged in the UK, with a reregulation of the industry now taking place with the aim of ensuring that retail investors are adequately informed about the risks of P2P lending. The UK saw some of the earliest developments in alternative lending platforms, with the 2005 establishment of Zopa offering peer-to-peer personal loans followed by the 2010 launch of Funding Circle offering small business loans. More than one hundred platforms have now been started in the UK and there has been rapid growth in total value of supported loans. ${ }^{19}$ Only a few platforms though operate on any scale, and at end-2017 only three intermediated more than $£ 0.5$ bn loans on their platforms: Funding Circle (small business loans $£ 1.6 \mathrm{bn}$ ), Zopa (personal loans $£ 1.2 \mathrm{bn}$ ) and Ratesetter (both personal and small business, $f 0.8 \mathrm{bn}$ ). ${ }^{20}$

Three phases can be distinguished. Initially, when still nascent, alternative lending largely fell under the regulatory radar. A second phase was the development of an initial framework for regulation in 2014-2016, after the transfer of regulatory responsibility from the Office of Fair Trading to the Financial Services Authority (superseded by the Financial

\footnotetext{
complex, time-consuming and expensive. Operators who choose to register their Platform Notes for sale to the general public must be prepared to devote substantial resources to the effort."

${ }^{18}$ As explained by Manbeck and Franson 2018, 'the term "accredited investor" includes most institutional investors and individuals who (i) individually, or with their spouse, have a net worth exceeding \$1 million exclusive of the value of the person's primary residence (and subject to certain adjustments for "underwater" mortgages), or (ii) individually had an income in excess of $\$ 200,000$ in each of the two preceding years, or had a joint income with spouse in excess of $\$ 300,000$ in each of those years, and have a reasonable expectation of reaching the same income level in the current year.'

${ }^{19}$ http://www.p2pmoney.co.uk/companies.htm lists 133 platforms as of early Nov 2018, including 30 that had stopped doing P2P or were no longer in operation.

${ }^{20}$ http://p2pfa.info, Ratesetter data from https://invest.ratesetter.com/aboutus/statistics
} 
Conduct Authority in 2013). This was given important political support by the $2010-2015$ coalition chancellor of the exchequer (finance minister) George Osborne. His March 2014 budget introduced the Innovative Finance Individual Savings Accounts (IFISAs) for alternative lending platforms. ${ }^{21}$ The third ongoing phase is focused on strengthening of regulation especially protection of retail investors.

A major concern of the FCA, when developing its initial framework for regulation of alternative lending in $2014 / 2016$ was ensuring that retail investors were fully aware that loan participations through alternative lending platforms are not at all similar to bank deposits. They are not covered by the Financial Services Compensation Scheme (the UK bank deposit insurance scheme) and that projected returns are not guaranteed with the possibility that investors could lose some of their initial investment. All the well-established platforms make clear on their webpages and during the process of investment that they are risky investments.

Another focus of the FCA was on systems and controls: applying its general requirements for regulated firms on adequacy of systems and controls and paying particular attention to segregation of client assets (ensuring these are not comingled with platform assets); and arrangements for orderly transfer of business in the event of platform failure. P2P platforms (o rwhat UK regulations terms 'loan-based crowdfunding platforms') are required to follow a scheme for segregation of client assets requirements (CASS or Client Asset Segregation Scheme) with applies to all regulated firms. Arrangements must also be in place to ensure that the servicing and administration of existing loans continue to be administered in the event of platform failure, with the transfer of loans to a third-party firm).

The FCA is now, in 2019, introducing a far more detailed regulatory regime. These will include a set of detailed and strengthened rules covering the wind-down of platforms. Here every platform must have detailed policies in place in the form of a 'resolution manual' describing in practical detail how a wind-down will be implemented. This must: (i) describe

\footnotetext{
${ }^{21}$ See (HM Revenues \& Customs 2015). The objective of this policy is described as "To increase the choice and flexibility available to ISA investors, encourage the growth of peer to peer lending and improve competition in the banking sector by diversifying the available sources of finance."
} 
arrangements that have been thoroughly assessed for their effectiveness, if necessary with external professional advice; (ii) give the regulators assurance that the contract terms agreed with investors and borrowers will be honoured even when the platform is no longer around to service them; and (iii) platforms must give clear information about the impact of any wind-down on both investors and borrowers. It will also contain much more explicit requirements on the systems and controls platforms need to have in place to support the claims they make to investors, for example about loan approvals and classifications and management of loan arrears.

The forthcoming regime also introduces much stronger rules on governance, aiming to bring platforms in line with the FCA's expectations of governance in investment management or in dealing, i.e. where properly fulfilling the fiduciary duties of an agent operating on behalf of a relatively uninformed client. They must have clearly stated risk management policies. Also, amongst their operational staffing responsibilities platforms must have independent risk-management, regulatory compliance and internal audit functions (for smaller platforms these functions can be combined with other responsibilities). Finally, they must demonstrate they are aware of and dealing appropriately with conflicts of interest, for example, opaque fee arrangements, participation in loans or loan markets by staff or family members or any other situation where decisions may potentially benefit a client or staff member at the expense of another client.

\section{The Future of China's P2P Sector}

As described above, the China's P2P sector has undergone a dramatic shake out and there is still no sign of halt. A reading of the newly designed regulations suggests that the initial plan of the government was certainly not to kill the whole industry, but to banish smaller platforms that are not mature or well-capitalized. That objective can be said has partly achieved: according to JP Morgan, the market share of the top 50 P2P companies in China has increased from about 35 per cent at the beginning of 2017 to 86 per cent at the end of last year. If the plan goes as anticipated, the market will eventually stabilize with 100 or so survivors. 
However, with the several changes of standard and repeated delay of deadlines since 2016, there is an increasing doubt in the industry in relation to the real intention of the central government. Recently, Hunan, Shangdong, Chongqing and Henan provinces announced there is no single platform in their respective jurisdictions has passed the test for registration (that is to say, all existing $\mathrm{P} 2 \mathrm{P}$ platforms in these jurisdictions must cease operating) (Hu, 2019).

Even if the central government indeed likes to retain the P2P sector, there is an increasing concern that whether there will be any survivor at all after the great cleanup? As the crisis unfolded, panic in the broader market led investors losing confidence and pulling their funds, this diminishing operators' liquidity and caused more failures of platforms, which in turn further undermining investors' confidence, a vicious cycle. As a result, even many prominent platforms have already closed down or are experiencing significant trouble. This pessimism reached its new peak in July 2019, when Lufax, the subsidiary of PingAn the Chinese Insurance giant and China's largest platform with outstanding loans of RMB 98.4bn (\$14.3bn), announced its withdrawal from P2P lending. Some thought this might signal death of the industry (Leung, 2019).

Our assessment of the future of Chinese P2P lending is a little less pessimistic. A major difference from the UK and the US is that years of financial repression are still limiting the supply of credit from the Chinese banking industry. As documented in the IMF's 2019 Article IV consultation (IMF (2019) bank lending in China continues to be dominated by loans to state owned enterprises which are actually increasing as a share of total loans. Loans to private enterprises are concentrated on larger businesses and there is a dearth of lending to SMEs. There will therefore continue to be substantial demand for SME lending from P2P platforms.

Another supportive factor is that the major Chinese technology firms are showing interest in P2P sector. Ant Financial Services, the parent of Alipay part owned by Alibaba the leading Chinese e-commerce, is viewed by investors as the most valuable global financial technology company in the world. The opportunity to leverage value from its 1.3 billion 
users of AliPay has led it to be valued at $\$ 150$ billion in $2018,50 \%$ larger than the Goldman Sachs with a market value of $\$ 99$ billion. Amongst several financial services activities that comprise Ant Financial Services is Zhao Cai Bao, launched in April 2014, a P2P lending facility embedded in Alipay that matches individual investors as lenders to individuals, micro businesses and SME borrowers.

Other P2P platforms may be supported by other major firms. The fourth largest internet tech company in China Jing Dong (after Alibaba, Tencent and Baidu) acquired the Xiamenbased P2P platform Yilidai in April 2019. ${ }^{22}$ Although the potential value of license is tempting, at this moment, other big players choose to wait and see, mainly due to the uncertainty over registration.

A further likely development is increasing participation of institutional investors in P2P lending as the Chinese investment industry itself matures shifting with the large volume of funds now being built up in new wealth management funds (Ant Financial Services rapidly growing funds such as Yu'E Bao a money market fund, Ant Fortune and AnTSDAQ are examples).

The strong desire by the Chinese authorities to maintain the flow of credit to SMEs, implying that they will continue to enforce regulation requirements on existing platforms fairly cautiously and gently. While investor protection will be an important concern, the need to balance this against the priority of maintaining the supply of credit will discourage a rigorous application of rules that might otherwise create a marked contraction of credit supply. For all these reasons we expect China to continue to have a strong non-bank lending industry, much of it employing the P2P 'information based lending model' encouraged by the new regulatory regime.

\footnotetext{
${ }^{22}$ This acquisition also illustrates the challenge of complying with the new registration requirements. Yilidai was latter was once considered as a candidate for registration by the local financial authority back to 2017, but seems to have preferred acquisition to obtaining the required investment capital from its previous owners (Sina, 2019).
} 


\section{Conclusions}

The rise and continuing rapid growth of alternative lending platforms - in the US, China and the UK- has been heralded as a fundamental technological challenge to traditional bank business models. The spectacular increase of P2P lending in China, with the volume of lending increasing sixty-fold over the course of only four years from 2013 to 2017 is the most dramatic example of this challenge to traditional bank business models.

We have reviewed the Chinese experience including the fallout from the employment of flawed business models employed by many Chinese P2P lenders based on inadequately supported platform guarantees. The collapse of unsound platforms, together with the introduction since 2015 of a comprehensive regulatory framework into what was previously entirely unregulated sector, has led to a substantial restructuring with the number of platforms already having fallen substantially by around one-fifth to less than 2,000 and expected to fall much further; and the volume of new lending now only one third of its 2017 peak.

This contraction and restructuring still has some way to go. But we anticipate that the larger platforms, those well positioned to comply with the new regulations and with substantial investor backing e.g. from some of the major internet commerce firms in China, will survive and continue to be a major provider of SME and personal loans. Chinese P2P lending is certainly down, but this is by no means a knock-out blow and after restructuring the volume of lending may well continue to substantially exceed that in other jurisdictions.

Alistair comment for Ding. I have said something about the swing of the regulatory pendulum in the Introduction. We need to revise this latter paragraph to better reflect the impression we have that the Chinese authorities are now introducing an especially tight regulatory regime and as a result there is great uncertainty about how many platforms will be able to continue with a P2P lending business model. I am thinking that many perhaps all will either have to become balance sheet lenders or banks with sufficient equity capital to support their loan risks or will have to wind down their activities. 


\section{References}

ACCA.2015."The Rise of Peer-to-peer lending in China: An Overview and Survey Case Study." https://www.accaglobal.com/content/dam/ACCA Global/Technical/manage/eachina-p2p-lending.pdf

Ahern, Deirdre M. 2018. "Regulatory Arbitrage in a FinTech World: Devising an Optimal EU Regulatory Response to Crowdlending."

Allen, Franklin, Qian Jun and Qian Meijun. 2005. "Law, finance and economic growth in China." Journal of Financial Economics 77, 57-116.

Alloway, Tracey, and Arash Massoudi. 2014." P2P Lenders Install 'Speed Bumps.'” Financial Times, Feburary 10, 2014. https://www.ft.com/content/4c55ae50-9035-11e3-a776$\underline{00144 f e a b 7 d e}$

Baxter, Lawrence G. 2011. “Capture in Financial Regulation: Can We Channel It toward the Common Good." Cornell JL \& Pub. Pol'y 21. HeinOnline: 175.

Cadwalader. 2018. “Marketplace Lending Update: Who's My Lender?" Cadwalader, $\begin{array}{lll}\text { Wickersham } \text { and Taft } & \text { LLP. }\end{array}$ https://www.cadwalader.com/uploads/cfmemos/9cf7d89d0e9c1e0ddaaebc58b8e8eec 3.pdf.

Caijing. 2018. "The Dismal End of Ezubao." May 28, 2018. http://finance.caijing.com.cn/20180528/4459893.shtml

Caixin. 2013. "The Stories Before and After the Establishment of Shanghai and Shenzhen Stock Exchanges", 1 January, 2013. available at http://reading.caixin.com/111459/111473.html

Cao, Pei. 2018. "Deadline for Recordation and Registration Comes Close, The Last One Kilometer for 10 Years' P2P Industry." Phoenix Weekly, April 5, 2018. http://www.ifengweekly.com/detil.php?id=5612

Chang, Soonpeel Edgar. 2018. "REGULATION OF CROWDFUNDING IN INDONESIA." Growth, 5.

Danisewicz, Piotr, and Ilaf Elard. 2018. "The Real Effects of Financial Technology: Marketplace Lending and Personal Bankruptcy." Available at SSRN 3208908.

Davidson, Jonathan. 2016. "Balancing Regulatory Objectives in the Dynamic Consumer Credit Market." London: Financial Conduct Authority. https://www.fca.org.uk/print/news/speeches/balancing-regulatory-objectives- 
dynamic-consumer-credit-market.

Davis, Erin, and Tara Rice. 2006. "Federal Preemption of State Bank Regulation: A Conference Panel Summary." Chicago Fed Letter, no. 230a. Federal Reserve Bank of Chicago: 1.

DavisPolk. 2018. “Federal Banking Regulators Can and Should Resolve Madden and True Lender Developments." New York. https://www.davispolk.com/publications/federalbanking-regulators-can-and-should-resolve-madden-and-true-lender-developments.

Eur-Young, Hwang. 2018. "FSC Reins in P2P Lending." Korea JoongAng Daily, June 18, 2018. http://koreajoongangdaily.joins.com/news/article/article.aspx?aid=3049440.

European Commission. 2017. "Identifying Market and Regulatory Obstacles to Crossborder Development of Crowdfunding in the EU." Brussels. https://ec.europa.eu/info/sites/info/files/171216-crowdfunding-report_en.pdf.

European Crowdfunding Network. 2017. "Review of Crowdfunding Regulation 2017." Brussels. https://eurocrowd.org/wpcontent/blogs.dir/sites/85/2017/10/ECN_Review_of_Crowdfunding_Regulation_2017. pdf.

FCA. 2016a. "Call for Input to the Post-Implementation Review of the FCA's Crowdfunding Rules." London. https://www.fca.org.uk/publication/call-for-input/call-inputcrowdfunding-rules.pdf.

- 2016b. "Guide for Consumer Credit Firms." https://www.fca.org.uk/publication/finalised-guidance/consumer-credit-beingregulated-guide.pdf.

- - . 2016c. "Interim Feedback to the Call for Input to the Post-Implementation Review of the FCA's Crowdfunding Rules." 16-13. Feedback Statement. London. https://www.fca.org.uk/publication/feedback/fs16-13.pdf.

- - . 2018. "Loan-Based ('Peer-to-Peer') and Investment-Based Crowdfunding Platforms: Feedback on Our Post-Implementation Review and Proposed Changes to the Regulatory Framework." London. https://www.fca.org.uk/publications/consultationpapers/cp18-20-loan-based-peer-peer-and-investment-based-crowdfunding-platformsfeedback-our-post.

Ferrarini, Guido. 2017. "Regulating FinTech: Crowdfunding and Beyond." European Economy, no. 2. Europeye srl: 121-42. 
Havrylchyk, Olena. 2018. "Regulatory Framework for the Loan-Based Crowdfunding Platforms." OECD.

HM Revenues \& Customs. 2015. “Income Tax: Innovative Finance Individual Savings Account and Peer to Peer Loans - GOV.UK." Www.Gov.Uk. 2015. https://www.gov.uk/government/publications/income-tax-innovative-financeindividual-savings-account-and-peer-to-peer-loans.

Honigsberg, Colleen, Robert J Jackson Jr, and Richard Squire. 2017. "How Does Legal Enforceability Affect Consumer Lending? Evidence from a Natural Experiment." The Journal of Law and Economics 60 (4). University of Chicago Press Chicago, IL: 673-712.

Hu, Zhijun. 'P2P Platforms Got Eliminated in another Province, No Single Platform Passed the Test, More than 1200 Platforms have Voluntarily Closed Down in This Year', 17 November, 2019, http://news.stcn.com/2019/1117/15498715.shtml

Hutchison, Connor. 2018. "The Future of Peer-to-Peer Lending in Canada." Ivey FinTech Club. 2018. https://medium.com/iveyfintechclub/the-future-of-peer-to-peer-lendingin-canada-66db882f5835.

IMF (2019), People's Republic of China 2019 Article IV Consultation Staff Report", August 2019.

Kezuka, Hiroyuki. 2017. “CROWDFUNDING IN JAPAN: Expanding as the Popular Measure to Success and Support." Centria-ammattikorkeakoulu.

Klöhn, Lars. 2018. "The Regulation of Crowdfunding in Europe." In The Economics of Crowdfunding, edited by Douglas J Cumming and Lars Hornuf, 219. Springer.

Kuntchev, Veselin; Ramalho, Rita; Meza, Jorge Rodriguez; Yang, Judy S. 2012. "What have we learned from the enterprise surveys regarding access to finance by SMEs?" Washington, DC: World Bank.

Lardy, Nicholas. 1998. China's Unfinished Economic Revolution, Brookings Institution Press

Leung, Danny. "Lufax withdrawal may signal death of China's P2P lending industry" 20 July, 2019 https://www.financeasia.com/article/lufax-withdrawal-may-signal-deathof-chinas-p2p-lending-industry/453201

Liu, Alfred. "China P2P Lending Crackdown May See 70\% of Firms Close”, 2 January 2019 https://www.bloomberg.com/news/articles/2019-01-02/china-s-online-lendingcrackdown-may-see-70-of-businesses-close

Lo, Benjamin. 2016a. “It Ain't Broke: The Case For Continued SEC Regulation of P2P 
Lending." Harvard Business Law Review 6 (Online): 87-110. http://www.hblr.org/2016/08/it-aint-broke-the-case-for-continued-sec-regulation-ofp2p-lending/.

- - . 2016b. "Online Lenders Shouldn't Get Mad Over Madden." J. Bus. Entrepreneurship \& L. 10. HeinOnline: 63.

Lufax. 2015. "P2P Lending Market in China."

http://blog.lendit.com/wp-content/uploads/2015/04/Lufax-white-paper-Chinese-P2PMarket.pdf

Manbeck, Peter, and Marc Franson. 2016. "The Regulation of Marketplace Lending: A Summary of the Principal Issues (2016 Update)."

- - . 2018. "The Regulation of Marketplace Lending: A Summary of the Principal Issues." https://www.chapman.com/insights-publications-

Regulation Marketplace Lending.html.

McKinnon, Ronald. 1973. Money and Capital in Economic Development. Washington, DC: Brookings Institution.

Megaw, Nicholas. 2018. "UK P2P Lender Looks into Selling the Loans on Its Platform." Financial Times, October 29, 2018. https://www.ft.com/content/a19cd1d8-db65-11e89f04-38d397e6661c.

Milne, Alistair. 2018. "Marketplace Lending: Business Models and Regulation in Australia and the UK."

Milne, Alistair, and Paul Parboteeah. 2016. "The Business Models and Economics of Peer-toPeer Lending." 2016, no 17. Research Report. Centre for European Policy Studies. http://papers.ssrn.com/sol3/papers.cfm?abstract_id=2763682.

Nahata, Pallavi. 2018. “Regulations Shrink India's Peer-to-Peer Lending Industry,” August 18, 2018. https://www.bloombergquint.com/business/regulations-shrink-indias-peer-topeer-lending-industry\#gs.awnIMRI.

Neuwirth, Suzie. 2017. "Wellesley Puts P2P Product on 'Pause' and Boosts Transparency." $\begin{array}{llll}\text { P2P Finance News, May } 2017 . & \end{array}$ http://www.p2pfinancenews.co.uk/2017/05/26/wellesley-p2p-pause-transparencyresults/.

Perkins, David W. 2018. "Marketplace Lending: Fintech in Consumer and Small-Business Lending." Washington DC. https://fas.org/sgp/crs/misc/R44614.pdf. 
Pranjivan,Vinay. 2017. "Financial Innovation and Alternative Finance: A Comparative Analysis of the Objectives of Regulation and Its Impact on Lending Based Crowdfunding in France and in the UK."

P2P Research Group. 2016. “P2P with Chinese Characteristics: Development, Regulation and Outlook." http://www.cf40.org.cn/uploads/research/20160115p2p.pdf

Samitsu, Atsushi. 2017. "Structure of P2P Lending and Investor Protection: Analyses Based on an International Comparison of Legal Arrangements." Bank of Japan.

Shen, Wei. 2015. "Internet Lending in China: Status Quo, Potential Risks and Regulatory

Options." Computer Law \& Security Review 31: 800

------.2016. "Shadow Banking in China: Risk, Regulation and Policy." Edward Elgar.

Sheng, Adrew, Ng Chowsoon and Edelmann, Christian. 2013. “Asia Finance 2020: Framing a

New Asian Financial Architecture."

https://www.oliverwyman.com/content/dam/oliver-

wyman/global/en/files/archive/2013/Asia Finance 2020.pdf

Sina, 2019“Jingdong Increased its Leverage in Online Lending by Acquiring Yilidai Platform",

10 April, 2019 https://finance.sina.com.cn/roll/2019-04-10/doc-

ihvhiqax1607697.shtml

The 2016 Blue Book of Internet Finance, Beijing: Qinghau University Press

Wardrop, Robert, and Tania Ziegler. 2016. " A Case of Regulatory Evolution-A Review of the

UK Finanical Conduct Authority's APP Roac H To Crowdfunding ." DICE Report 14 (2).

CES-IFO GmbH: 23.

Wildau, Gabriel, and Yizhen Jia. 2018. "Collapse of Peer-to-peer Lenders Sparks Investors

Flight." Financial Times, June 22, 2018. https://www.ft.com/content/75e75628-8b2711e8-bf9e-8771d5404543

Wilmarth Jr, Arthur E. 2004. "OCC's Preemption Rules Exceed the Agency's Authority and Present a Serious Threat to the Dual Banking System and Consumer Protection, The." Ann. Rev. Banking \& Fin. L. 23. HeinOnline: 225.

Yiling Caijing, 2019. “Important News-Pilot Programme for P2P Registration 8 April,2019 http://bank.jri.com.cn/2019/04/09164427354891.shtml 